\title{
Nitrogen fixation by caucasian clover and white clover in irrigated ryegrass pastures
}

\author{
K.H. WIDDUP ${ }^{1}$, R.G. PURVES ${ }^{2}$, A.D. BLACK ${ }^{3}$, P. JARVIS ${ }^{3}$ and R.J. LUCAS $^{3}$ \\ ${ }^{1}$ AgResearch, PO Box 60, Lincoln \\ ${ }^{2} 148$ Fisher Avenue, Beckenham, Christchurch \\ ${ }^{3}$ Soil, Plant and Ecological Sciences Division, PO Box 84, Lincoln University \\ keith.widdup@agresearch.co.nz
}

\begin{abstract}
The $\mathrm{N}_{2}$ fixation ability of caucasian clover was compared with that of white clover in irrigated ryegrass pastures over years 2 and 3 of a grazing experiment, using the ${ }^{15} \mathrm{~N}$ enrichment technique. 'Endura' caucasian clover was inoculated with the specific Rhizobium strain ICC148. The N concentration in clover herbage and the proportion of clover $\mathrm{N}$ derived from $\mathrm{N}_{2}$ fixation $\left(\mathrm{P}_{\mathrm{N}}\right)$ were similar for both clovers at averages of $4.6 \% \mathrm{~N}$ and $50-60 \%$ respectively over the 2 years. The amount of $\mathrm{N}_{2}$ fixed per hectare was directly related to the amount of clover dry matter (DM) produced by the two clover species. Caucasian clover produced four times the DM yield of white clover in year 2 (5400 cf. $1450 \mathrm{~kg} \mathrm{DM} / \mathrm{ha}$ ) and four times the amount of $\mathrm{N}_{2}$ fixed in herbage (136 cf. $36 \mathrm{~kg} \mathrm{~N} /$ ha). In year 3 , caucasian clover produced $50 \%$ more clover DM (3450 cf. $2370 \mathrm{~kg} \mathrm{DM} / \mathrm{ha}$ ) and $\mathrm{N}_{2}$ fixed (98 cf. $66 \mathrm{~kg} \mathrm{~N} / \mathrm{ha}$ ) than white clover. The increased $\mathrm{N}$ input from caucasian clover increased grass $\% \mathrm{~N}$ and $\mathrm{N}$ uptake from soil in caucasian clover pastures resulting in higher total pasture production compared with white clover pastures (15.7 cf. $14.2 \mathrm{t} \mathrm{DM} / \mathrm{ha}$ ) by year 3 . In this study, caucasian clover demonstrated greater potential than white clover to meet the $\mathrm{N}$ demands of high-yielding perennial ryegrass in an intensive pastoral system.
\end{abstract}

Keywords: clover content, Lolium perenne, nitrogen fixation, pasture production, Trifolium ambiguum, T. repens

\section{Introduction}

Biological nitrogen $\left(\mathrm{N}_{2}\right)$ fixation by legumes is both ecologically and economically important to pastoral farming in New Zealand (Walker 1995). White clover (Trifolium repens) is the predominant legume used and studies have shown that annual $\mathrm{N}_{2}$ fixation levels averaged $185 \mathrm{~kg} \mathrm{~N} / \mathrm{ha} /$ year over $10 \mathrm{New}$ Zealand sites (Hoglund et al. 1979). At Kirwee, Canterbury, dryland and irrigated pastures fixed 120 and $190 \mathrm{~kg} \mathrm{~N} /$ ha/year respectively (Crush 1979). New Zealand's white cloverbased pastures, however, are not fixing sufficient nitrogen to support the demands of high-yielding grasses nor to provide enough quality feed for maximum animal production (Caradus et al. 1996; Chapman et al. 1995; Clark \& Harris 1995).

Caucasian clover (Trifolium ambiguum) has been demonstrated recently to have potential in lowland, intensive farming systems where it has consistently produced greater total legume yields than white clover in mixed pastures (Black et al. 2000; Moss et al. 1996; Watson et al. 1996). The performance of caucasian clover improved after the selection of the specific Rhizobium strain ICC148. Inoculation with this strain resulted in improved establishment, more effective nodules and greater $\mathrm{N}_{2}$ fixation especially in high country pastures (Pryor et al. 1998). The grazing experiment established at Lincoln University in December 1996 (Black et al. 2000) to compare caucasian- and white clover-based ryegrass swards provided the resource to measure the $\mathrm{N}_{2}$ fixation ability of caucasian clover and compare it with that of white clover.

\section{Material and methods}

The layout and management of the grazing experiment at Lincoln University was described by Black et al. (2000). The experiment was sown in December 1996 with either 'Endura' caucasian clover or 'Demand' white clover at high or low soil fertility with eight replicates. The 'Endura' caucasian clover seed was inoculated with the specific Rhizobium strain ICC148 (Pryor et al. 1998). 'Ruanui' zero endophyte ryegrass was direct-drilled into the pure clover swards in March 1997. The $\mathrm{N}_{2}$ fixation study was initiated in spring 1998. It used five replications of the two clover treatments under high soil fertility (Olsen P of 22). The experiment was irrigated over the summer period (December-March) of the 2 years.

The ${ }^{15} \mathrm{~N}$ enrichment method (Ledgard et al. 1985) was used to measure $\mathrm{N}_{2}$ fixation. Commencing in October 1998, labelled ammonium sulphate (40 atom\% ${ }^{15} \mathrm{~N}$ ) at $0.05 \mathrm{~g} \mathrm{~N} / \mathrm{m}^{2}$ was applied to $1.45 \mathrm{~m}^{2}$ of pasture in the 10 plots (two clovers $\mathrm{x}$ five replicates) and exclosure 
cages were placed over the treated areas. The pasture in the treated areas was selected to ensure that adequate populations of the treatment clover species were present. In the caucasian clover plots, ${ }^{15} \mathrm{~N}$ was applied to areas with minimal amounts of volunteer white clover. A $0.25 \mathrm{~m}^{2}$ quadrat was cut from each treated area approximately every 4 weeks and sub-samples from these cuts were dissected into clover and grass components before drying to determine dry matter (DM) yield and botanical composition. Separate additional subsamples of the clover and grass herbage were dried and ground for $\% \mathrm{~N}$ and ${ }^{15} \mathrm{~N}$ analysis using a mass spectrometer (Anca 20-20 stable isotope analyser). After every second cut, ${ }^{15} \mathrm{~N}$ was re-applied to all 10 plots. The ${ }^{15} \mathrm{~N}$ treated areas were not moved in 1998/1999 but new areas were selected and treated with ${ }^{15} \mathrm{~N}$ every second cut (8weekly) in 1999/2000. The plots were sampled six times between November 1998 and June 1999 (year 2 of the grazing experiment) and then eight times between October 1999 and June 2000 (year 3).

The proportion (\%) of $\mathrm{N}$ fixed by the clovers from atmospheric $\mathrm{N}_{2}\left(\mathrm{P}_{\mathrm{N}}\right)$ was calculated by:

\section{$\mathrm{P}_{\mathrm{N}}=100 \mathrm{x}$ (atoms $\%{ }^{15} \mathrm{~N}_{\text {grass }}-$ atoms $\left.\%{ }^{15} \mathrm{~N}_{\text {clover }}\right) /$}

(atoms $\%{ }^{15} \mathrm{~N}_{\text {grass }}-\mathrm{B}$ )

where $\mathrm{B}=0.3663$, the atoms $\%{ }^{15} \mathrm{~N}$ of atmospheric $\mathrm{N}_{2}$.

The amount of fixed $\mathrm{N}(\mathrm{kg} / \mathrm{ha})$ in the cut clover herbage was then given by:

Fixed $\mathrm{N}=$ clover $\mathrm{DM}(\mathrm{kg} / \mathrm{ha}) \times$ clover $\% \mathrm{~N} / 100 \times \mathrm{P}_{\mathrm{N}} /$ 100

\section{Results}

\section{Mean herbage $\% \mathrm{~N}, \mathrm{P}_{\mathrm{N}}$ and $\mathrm{N}_{2}$ fixation}

Mean $\% \mathrm{~N}$ in clover herbage was similar for both caucasian and white clover during 1998/1999 and 1999/ 2000 (Table 1). The proportion of the $\mathrm{N}$ derived from $\mathrm{N}_{2}$ fixation $\left(\mathrm{P}_{\mathrm{N}}\right)$ was also similar for caucasian and white clover. In both clover species, $\mathrm{N}_{2}$ fixation contributed an average of between $50 \%$ and $60 \%$ of their herbage $\mathrm{N}$ over the 2 years (Table 1 ). The $\mathrm{P}_{\mathrm{N}}$ was highest in late spring-summer at about $75 \%$ and lowest in late autumn at $45 \%$ for both clovers.

In year 2, caucasian clover fixed more $\mathrm{N}$ than white clover throughout the whole growing season (Table 1,
Figure 1). In year 3, the $\mathrm{N}$ fixed by caucasian clover was greater in the summer period but similar to white clover in the cooler autumn period (Figure 1). It is likely that the low December values in year 3 were owing to low soil moisture levels, as irrigation was not initiated on the pastures until mid-December. Mean $\% \mathrm{~N}$ in grass herbage was significantly higher in the grass growing with caucasian clover than in the white clover based pastures during both years (Table 1).

\section{Pasture DM production}

In 1998/1999, the caucasian- and white clover-based pastures produced similar total DM (grass plus clover), however, clover DM production was greater from caucasian than white clover pastures (Table 2). DM production from the associated grass in caucasian clover pastures was lower than from white clover pastures (Table 2).

Table $\llbracket 2$ Total pasture, clover and grass production from caucasian- and white clover-based swards growing with perennial ryegrass, in high fertility soil, under irrigation, during year 2 (November 1998 to June 1999) and year 3 (October 1999 to June 2000).

\begin{tabular}{|c|c|c|c|c|}
\hline \multirow[b]{2}{*}{ Treatments } & \multirow[b]{2}{*}{$\begin{array}{c}\text { Clover content } \\
(\%)\end{array}$} & \multicolumn{3}{|c|}{ DM production (kg DM/ha/yr) } \\
\hline & & Clover & Grass & $\begin{array}{c}\text { Total } \\
\text { pasture }\end{array}$ \\
\hline & & --- Yea & 2 & \\
\hline Caucasian clover & 52.8 & 5400 & 4440 & 10,080 \\
\hline White clover & 15.1 & 1450 & 7440 & 9160 \\
\hline Isd (5\%) & $21.8^{*}$ & $2540^{*}$ & $2950 *$ & 2190ns \\
\hline & & --- Yea & $3-----$ & \\
\hline Caucasian clover & 21.9 & 3450 & 11,970 & 15,740 \\
\hline White clover & 16.8 & 2370 & 11,830 & 14,200 \\
\hline Isd $(5 \%)$ & $4.8^{*}$ & 940 * & $439 n s$ & $918^{*}$ \\
\hline
\end{tabular}

ns $=$ not significantly different at $\mathrm{P}>0.05$

* $=$ significant at $\mathrm{P}<0.05$ 
Figure $1 \mathrm{~N}$ fixed in caucasian and white clover herbage growing with perennial ryegrass in high fertility soil under irrigation during 1998/ 1999 and 1999/2000 (ns = non-significant at $\mathrm{P}>0.05$ and * = significant at $\mathrm{P}<0.05$ ).

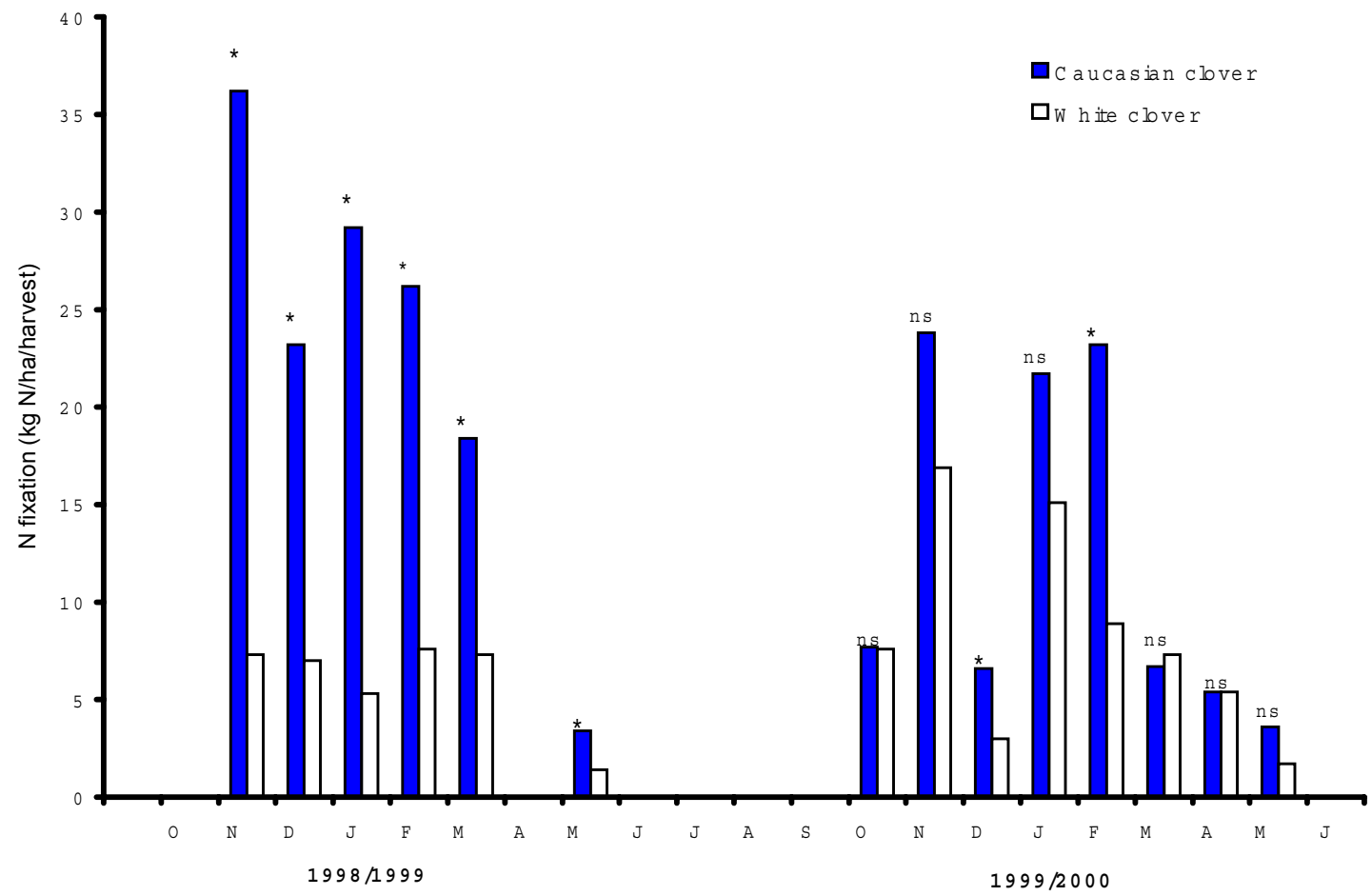

In 1999/2000, the caucasian clover-based pastures produced greater total DM compared with pastures sown with white clover (Table 2). The grass DM were similar from both pastures, but clover DM was greater from caucasian clover than white clover pastures $(22 \%$ cf. $17 \%$ clover) resulting in the greater total pasture production. Volunteer white clover produced $340 \mathrm{~kg}$ $\mathrm{DM} / \mathrm{ha}(10 \%$ of the total clover yield) in the caucasian clover pastures in year 3 .

\section{Discussion}

Caucasian clover and white clover had similar proportions of fixed $\mathrm{N}_{2}\left(\mathrm{P}_{\mathrm{N}}\right)$ in their herbage, which indicates that both clovers have a similar ability to fix $\mathrm{N}_{2}$ in the presence of perennial ryegrass, under irrigation and in high fertility soil. The amount of $\mathrm{N}_{2}$ fixed per hectare was directly related to the amount of DM produced by the two clover species. Caucasian clover produced four times more DM than white clover in year 2 (5400 cf. $1450 \mathrm{~kg} \mathrm{DM} / \mathrm{ha}$ ) and this was associated with four times the amount of $\mathrm{N}$ fixed (136 cf. $36 \mathrm{~kg} \mathrm{~N} /$ ha). In year 3 , caucasian clover produced $50 \%$ more DM than white clover; the amount of $\mathrm{N}$ fixed ( $\mathrm{kg} \mathrm{N} / \mathrm{ha} /$ yr) from $\mathrm{N}_{2}$ fixation in the caucasian clover pastures was therefore $50 \%$ greater than that in the white clover pastures.

Mean $\% \mathrm{~N}$ in clover herbage was similar for both clover species and was constant throughout the year, but the clovers showed variation in $\mathrm{P}_{\mathrm{N}}$ across seasons of the year. The $\mathrm{P}_{\mathrm{N}}$ was highest in late spring-summer $(75 \%)$ and lowest in autumn $(45 \%)$ for both clover species. Ledgard et al. (2001) attributed lower $\mathrm{P}_{\mathrm{N}}$ levels over autumn and early spring to low temperatures reducing clover growth, and/or elevated soil inorganic $\mathrm{N}$ during these periods. The level of soil inorganic $\mathrm{N}$ has a major modifying action on clover $\mathrm{N}_{2}$ fixation - as soil inorganic $\mathrm{N}$ availability increases, $\mathrm{N}_{2}$ fixation decreases (Hoglund et al. 1979). High $\mathrm{P}_{\mathrm{N}}$ occurred in late spring-summer when high temperatures increased clover growth rates and soil inorganic $\mathrm{N}$ levels are normally lower owing to rapid growth and high $\mathrm{N}$ uptake by grass.

The association between caucasian clover and the specific Rhizobium strain ICC148 was obviously very effective and productive in this experiment. The only other reported $\mathrm{N}_{2}$ fixation values from caucasian clover under grazing in New Zealand indicated lower values than white clover (Watson et al. 1996), but they suggested the acetylene reduction technique and shallow 
(75 mm) depth of sampling used were not appropriate for caucasian clover. In addition, the Rhizobium strain CC283B used in that experiment has since been surpassed by the new strain ICC148 with improved $\mathrm{N}_{2}$ fixation ability (Pryor et al. 1998).

The ${ }^{15} \mathrm{~N}$ enrichment method provides an accurate estimate of the amount of fixed $\mathrm{N}$ in the harvested clover herbage. However, this is likely to be an underestimate of total $\mathrm{N}$ fixed because it does not account for fixed $\mathrm{N}$ in clover stolons, rhizomes and roots. Jørgensen \& Ledgard (1997) showed the amount of fixed $\mathrm{N}$ in stolons and roots of white clover averaged $70 \%$ of that in clover herbage. Therefore, a 1.7 multiplying factor was used to give an estimate of the total $\mathrm{N}$ fixed. Using this conversion factor, the white clover-based pastures produced 61 and $112 \mathrm{~kg} \mathrm{~N} / \mathrm{ha}$ in years 2 and 3 respectively while the caucasian clover pastures produced 232 and $167 \mathrm{~kg} \mathrm{~N} / \mathrm{ha}$ (Table 1).

This method of estimating the total $\mathrm{N}$ fixed is likely to underestimate the value even more for caucasian clover as its shoot:root ratio is 30:70 compared with the 60:40 ratio for white clover (Widdup et al. 1998). If the same principles were applied to caucasian clover, the multiplying factor would be 3.3. However, this is likely to be an overestimate as much of the rhizome tissue is a storage organ and only the $\mathrm{N}$ in the newly grown rhizome tissue would reflect the $\mathrm{N}_{2}$ fixation during any regrowth period. Further studies are required to provide estimates of the fixed $\mathrm{N}$ in the above-ground herbage compared with below-ground rhizome/root tissues of caucasian clover.

Many New Zealand white clover-based pastures have average clover contents less than 20\% (Ettema \& Ledgard 1992; Moss 1987). This is generally considered insufficient to support the $\mathrm{N}$ requirements of highyielding grasses nor to provide enough quality feed for maximum animal performance (Caradus et al. 1996; Chapman et al. 1995; Clark \& Harris 1995). Thomas (1992) estimated clover contents of $20-45 \%$ could provide the $\mathrm{N}$ requirements of a sustainable and productive pasture. Caucasian clover has shown potential to approach these target clover contents when in association with aggressive grass species in irrigated (Black et al. 2000; Moss et al. 1996) and dryland (Black \& Lucas 2000; Watson et al. 1996) environments. In this experiment, caucasian clover pastures had a higher clover content and fixed more $\mathrm{N}_{2}$ than white clover pastures during both years. Caucasian clover pastures did, however, have exceptionally high clover contents in year 2 , which can be partly explained by the management of the $\mathrm{N}_{2}$ fixation plots. Fourweekly cutting with no excreta return for 8 months accentuated the clover component and depressed the grass component. Even though both clover species received the same cutting management, caucasian clover displayed greater growth potential than white clover under the repeated cutting regime.

In year $3,{ }^{15} \mathrm{~N}$ was applied to a new caged area every 8 weeks, a management allowing greater exposure of plots to normal grazing and excreta return; the clover contents were lower than in year 2 . The lower clover contents were also attributed to a heavy infestation of grass grub (Costelytra zealandica) in autumn 1999 (averaged 180 grubs $/ \mathrm{m}^{2}$ ) which greatly reduced the shoot and root material of both clover species (Trevor Jackson, pers. comm.). In spring 1999, white clover had recovered from surviving stolon pieces and new seedlings whereas the recovery of caucasian clover depended solely on new rhizome development from surviving rhizomes and tap-roots. Despite this disadvantage, caucasian clover produced significantly more clover herbage than white clover in the third year.

High $\mathrm{N}$ fixation by legumes in mixed pastures leads to greater $\mathrm{N}$ input into soil organic $\mathrm{N}$ resulting in increased $\mathrm{N}$ availability to associated grasses. In this study, the grass $\% \mathrm{~N}$ and the total soil $\mathrm{N}$ uptake was greatest in caucasian clover-based pastures by year 3 (Table 1 and 3) which resulted in higher total pasture production during year 3 (Table 2). This response needs to be monitored further at the Lincoln University grazing experiment to determine whether caucasian clover can maintain higher clover and total production than white clover in an environment with high soil $\mathrm{N}$.

Table $\ 3$ Total Soil $\mathrm{N}$ uptake ( $\mathrm{kg} \mathrm{N} / \mathrm{ha} / \mathrm{year})$ in caucasian cloverand white clover-based pastures during year 2 (November 1998 to June 1999) and year 3 (October 1999 to June 2000).

\begin{tabular}{|c|c|c|c|}
\hline \multirow[b]{2}{*}{ Treatments } & \multicolumn{3}{|c|}{------- Soil N uptake (kg N/ha/yr) ------- } \\
\hline & Grass N & Legume $\mathrm{N}^{\#}$ & Total Soil N \\
\hline $\begin{array}{l}\text { Caucasian clover } \\
\text { White clover } \\
\text { Isd }(5 \%)\end{array}$ & $\begin{array}{c}167 \\
252 \\
117 \mathrm{~ns}\end{array}$ & $\begin{array}{c}\text { Year } 2 \\
111 \\
32 \\
52^{*}\end{array}$ & $\begin{array}{c}276 \\
281 \\
87 n s\end{array}$ \\
\hline $\begin{array}{l}\text { Caucasian clover } \\
\text { White clover } \\
\text { Isd }(5 \%)\end{array}$ & $\begin{array}{l}414 \\
369 \\
17^{*}\end{array}$ & $\begin{array}{l}69 \\
43 \\
18^{*}\end{array}$ & $\begin{array}{l}483 \\
412 \\
29^{*}\end{array}$ \\
\hline
\end{tabular}

\# Legume $N$ uptake from soil = Legume $D M * \% N *\left(1-P_{N} / 100\right)$

$\mathrm{ns}=$ not significantly different at $\mathrm{P}>0.05$

* $=$ significant at $\mathrm{P}<0.05$

\section{Conclusions}

1. Both caucasian clover and white clover had similar proportions of fixed $\mathrm{N}_{2}$ in their herbage. This indicates that both clovers had a similar $\mathrm{N}$-fixing ability in the presence of perennial ryegrass, irrigation and high fertility soil. 
2. The amount of $\mathrm{N}$ fixed per hectare by caucasian and white clover was directly related to the herbage DM produced by the two clover species. Caucasian clover produced four times the DM and total $\mathrm{N}$ fixed of white clover in year 2 of the grazing experiment and $50 \%$ more DM and $\mathrm{N}$ fixed in year 3 . The total $\mathrm{N}$ fixed ranged from $167-232 \mathrm{~kg} \mathrm{~N} /$ ha for caucasian clover and $61-112 \mathrm{~kg} \mathrm{~N} / \mathrm{ha}$ for white clover.

3. In the caucasian clover-based pastures, the increased $\mathrm{N}$ input from the clover had lead to greater soil $\mathrm{N}$ uptake by the associated grasses by year 3 resulting in higher total pasture production. Further study is required to better quantify soil $\mathrm{N}$ changes and changes in total pasture production over time.

\section{ACKNOWLEDGEMENTS}

The authors acknowledge funding from the Struthers Trust for the development of the grazing experiment at Lincoln University and FRST funding for provision of ${ }^{15} \mathrm{~N}$ and $\mathrm{N}$ analyses.

The assistance of Bruce Pownall for the supply of ewe lambs and maintaining animal health, Keith Pollock and Jo Amyes for field assistance and Stuart Larsen and Roger Cresswell for conducting the $\mathrm{N}$ analyses are thanked. We thank the C. Alma Baker and Struthers Trusts for providing A.D. Black with financial support from post-graduate scholarships.

\section{REFERENCES}

Black, A.D.; Pollock, K.M.; Lucas, R.J.; Amyes, J.M.; Pownall, D.B.; Sedcole, J.R. 2000. Caucasian clover/ryegrass produced more legume than white clover/ryegrass pastures in a grazed comparison. Proceedings of the New Zealand Grassland Association 62: 69-74.

Black, A.D.; Lucas, R.J. 2000. Caucasian clover was more productive than white clover in grass mixtures under drought conditions. Proceedings of the New Zealand Grassland Association 62: 183-188.

Caradus, J.R.; Harris, S.L.; Johnson, R.J. 1996. Increased clover content for increased milk production. Proceedings of the Ruakura Farmers' Conference 48: 42-49.

Chapman, D.F.; Parsons, A.J.; Schwinning, S. 1995. Management of clover in grazed pastures: expectations, limitations and opportunities. White clover: New Zealand's Competitive Edge. Agronomy Society of New Zealand Special Publication 11/ Grassland Research and Practice Series 6: 55-64.

Clark, D.A.; Harris, S.L. 1995. White clover or nitrogen fertiliser for dairying? White clover: New Zealand's Competitive Edge. Agronomy Society of New
Zealand Special Publication 11/Grassland Research and Practice Series 6: 107-114.

Crush, J.R. 1979. Nitrogen fixation in pasture. IX. Canterbury Plains, Kirwee. New Zealand Journal of Experimental Agriculture 7: 35-38.

Ettema, P.J.; Ledgard, S.F. 1992. Getting the best out of white clover. Proceedings of the Ruakura Farmers' Conference 44: 72-76.

Hoglund, J.H.; Crush, J.R.; Brock, J.L.; Ball, R. 1979. Nitrogen fixation in pasture. XII. General Discussion. New Zealand Journal of Experimental Agriculture 7: 45-51.

Jørgensen, F.V.; Ledgard, S.F. 1997. Contribution from stolons and roots to estimates of the total amount of $\mathrm{N}_{2}$ fixed by white clover. Annals of Botany 80: 641-648.

Ledgard, S.F.; Simpson, J.R.; Freney, J.R.; Bergersen, F.J. 1985. Field evaluation of ${ }^{15} \mathrm{~N}$ techniques for estimating nitrogen fixation in legume-grass associations. Australian Journal of Agricultural Research 36: 663-676.

Ledgard, S.F.; Sprosen, M.S.; Penno, J.W.; Rajendram, G.S. 2001. Nitrogen fixation by white clover in pastures grazed by dairy cows: Temporal variation and effects of nitrogen fertilization. Plant and Soil 229: 177-187.

Moss, R.A. 1987. Pasture and animal performances on an irrigated sheep production farmlet. Winchmore Irrigation Research Station Technical Report 24: 4-7.

Moss, R.A.; Burton, R.N.; Allan, B.E. 1996. Productivity of Caucasian clover based pastures under irrigation. Proceedings of the New Zealand Grassland Association 58: 177-181.

Pryor, H.N.; Lowther, W.L.; McIntyre, H.J.; Ronson, C.W. 1998. An inoculant Rhizobium strain for improved establishment and growth of hexaploid Caucasian clover. New Zealand Journal of Agricultural Research 41: 179-189.

Thomas, R.J. 1992. The role of legumes in the nitrogen cycle of productive and sustainable pastures. Grass and Forage Science 47: 133-142.

Walker, T.W. 1995. The value of $\mathrm{N}$-fixation to pastoral agriculture in New Zealand. White clover: New Zealand's Competitive Edge. Agronomy Society of New Zealand Special Publication 11/Grassland Research and Practice Series 6: 115-118.

Watson, R.N.; Neville, F.J.; Bell, N.L.; Harris, S.L. 1996. Caucasian clover as a pasture legume for dryland dairying in the coastal Bay of Plenty. Proceedings of the New Zealand Grassland Association 58: 183-188.

Widdup, K.H.; Knight, T.L.; Waters, C.J. 1998. Genetic variation for rate of establishment in caucasian clover. Proceedings of the New Zealand Grassland Association 60: 213-217. 